\title{
Geosciences Geociências
}

\section{Diamonds from Borrachudo River, São Francisco Basin (Tiros, MG): Morphologic and Dissolution Aspects Diamantes do rio Borrachudo, bacia do São Francisco (Tiros, MG): aspectos morfológicos e de dissolução}

\begin{abstract}
Luis Alberto de Deus Borges
Geologist of the Petrus Mineração

Patos de Minas, Minas Gerais, Brasil

petrus@petrusminera.com
\end{abstract}

\section{Mario Luiz de Sá Carneiro Chaves \\ Associate Professor \\ Universidade Federal de Minas Gerais \\ Instituto de Geociências \\ Belo Horizonte - Minas Gerais - Brasil \\ mlschaves@gmail.com}

\section{Joachim Karfunkel}

Associate Professor

Universidade Federal de Minas Gerais Instituto de Geociências

Belo Horizonte - Minas Gerais - Brasil

jkarfunkel@yahoo.com

\begin{abstract}
A representative set of diamonds from the Borrachudo River (114 stones) was described for the first time as to their physical characteristics, among them weight, morphology, dissolution figures, and abrasion. Most samples are low in weight ( $51 \%$ less than $0.30 \mathrm{ct}$ ) and only $\sim 3.5 \%$ are above $3.0 \mathrm{ct}$. However, considering the total weight, $47 \%$ of it is concentrated in the range above $3 \mathrm{ct}$. On the other hand, there even occur diamonds with dozen of carats. The most common crystallographic forms are originated from the octahedral form by dissolution, although irregular shapes like chips and flats also occur. The diamonds show differences in form compared to their weight ranges; those up to $0.30 \mathrm{ct}$ have various shapes; in the range of 0.31 to $1 \mathrm{ct}$ the most common are octahedral forms and their descendants; and in stones larger than $1 \mathrm{ct}$ chips and flats predominate. The general habitus of the crystals, identified by their final tetrahexahedroid shapes, chips and flats, corroborated by the dissolution figures, indicate that the diamond were submitted to strong dissolution in a magmatic environment. Residual hillocks and holes represent the final stage of dissolution. The study indicates that the abrasion by the fluvial transport was not expressive enough to cause mechanical wear, thus ca. 97\% shows no sign of wear. This fact suggests a proximal source for most of these diamonds.
\end{abstract}

Keywords: Diamond, Borrachudo River, São Francisco Basin

\section{Resumo}

Uma população representativa de diamantes do rio Borrachudo (114 cristais) é pela primeira vez descrita quanto às suas características físicas, envolvendo peso, morfologia, figuras de dissolução e abrasão. A maioria das amostras possui peso reduzido $(\sim 51 \%$ inferior a $0,30 \mathrm{ct})$ e apenas $\sim 3,5 \%$ acima de 3,0 ct. No entanto, em relação ao peso total, $\sim 47 \%$ concentra-se na faixa de peso acima de $3 \mathrm{ct}$, sendo observados, ainda, diamantes com dezenas de quilates. As formas cristalográficas mais comuns são oriundas da dissolução da forma original octaédrica, embora formas irregulares como chips e flats também ocorram. Os diamantes apresentam diferenciações quanto às suas formas em relação às faixas de peso; os com até 0,30 ct mostram-se em formas variadas; entre 0,31 a 1 ct ocorrem formas octaédricas e suas descendentes; e, nas amostras maiores que $1 \mathrm{ct}$, predominam os chips e flats. $\mathrm{O}$ habitus geral dos cristais, identificado pelas formas tetraedróides finais, chips e flats, juntamente com as figuras de dissolução, indicam que os diamantes sofreram uma forte dissolução no ambiente magmático. No estágio final do processo, são, ainda, observadas figuras de corrosão como hillocks residuais e buracos. O estudo da abrasão fluvial indica que o transporte 
não foi expressivo para causar desgaste mecânico, logo cerca de $97 \%$ não apresenta sinais abrasivos. Este fato sugere uma fonte proximal para a maioria desses diamantes.

Palavras chaves: Diamante, Rio Borrachudo, Bacia do São Francisco

\section{Introduction}

The Borrachudo River is a left margin tributary of the São Francisco River, flowing in NE-SW direction parallel to the Abaeté (west) and Indaiá (east) rivers, both also diamondiferous (Figure 1). Diamonds were discovered in the Abaeté River, considered the richest among the three, in the mid-eighteenth century by runaway slaves from the Diamantina District, which was at this time the main area of the country where the mineral was explored (Barbosa, 1991).

Since 2001, a paleochannel located on the banks of the Borrachudo River, in the locality called Canastrão (municipality of Tiros, Minas Gerais State), has been exploited by Petrus Mineração, a company from Patos de Minas (Figure $1)$. The objective of this research is the study of a complete parcel of diamonds,

\section{Regional geology and diamond deposits}

The focused area is part of the "Western São Francisco Diamondiferous Province" (Chaves \& Chambel, 2003), one of the four major diamond provinces of Minas Gerais. No detailed study of this region has been made, although it has been mapped recently at a 1:100,000 scale (Reis, 2011). The oldest rocks belong to the Canastra and Bambuí groups, of Neoproterozoic ages (Figure 1), consisting mostly of quartzites for the first group, and metasilt-

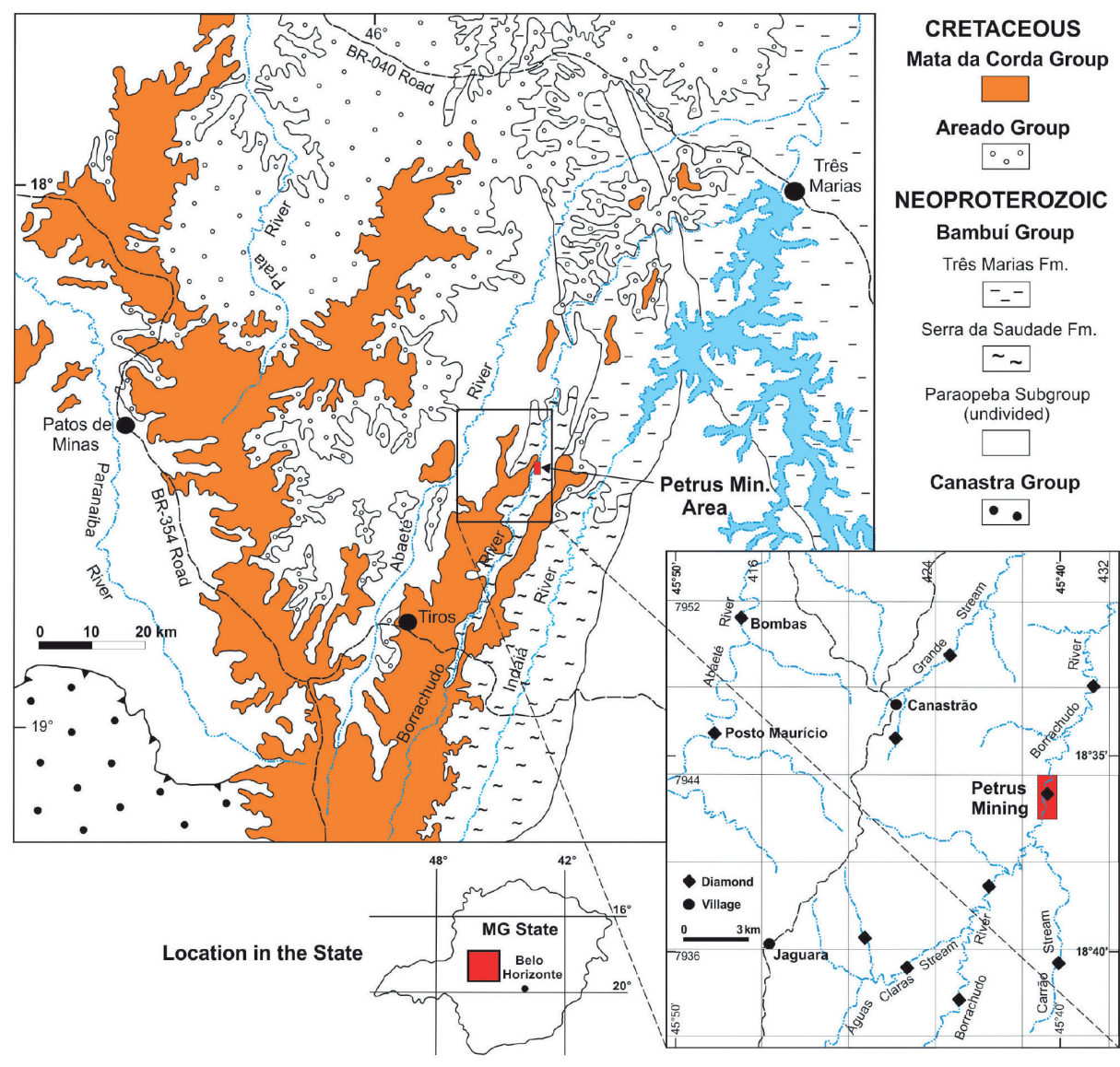

The covering sediments of the Precambrian rocks have been deposited mainly during the Cretaceous Era. The oldest deposits correspond to the Areado Group (Lower Cretaceous), consisting of thin grained sandstones with large cross stratifications, and the Mata da Corda Group (Upper Cretaceous) which consists of sandstones and volcanoclastic rocks. Local unconsolidated sandy sediments with 114 stones, recovered of this alluvial mine during the first half of 2010 . The study emphasizes the morphological aspects of the diamonds, as well as their relationships with the different types of dissolution and/or abrasion. The source rock(s) of such diamonds in the region is still unknown.

stones with interbedded limestones for the latter group, which were folded and metamorphosed during the Brasiliano orogenic cycle (0.65 to $0.50 \mathrm{Ga}$ ).

Figure 1

Geological map of the region related to the Abaeté, Borrachudo and Indaiá rivers, in the center-west of Minas Gerais State (modified from Heineck et al., 1993). In detail, on the right side, diamond occurrences in the Borrachudo River and its surroundings (Borges, 2013).

(Tertiary?) also occur, probably formed by the dismantlement of the underlying deposits. The important fracturing pattern observed, responsible for the SSW-NNE direction of major drainages, apparently 
follows a normal fault system that was originated from extensional events (Fuck $\&$ Pereira, 2005). The diamond deposits of this region and their possible source have been the subject of studies by some authors (e.g. Barbosa et al., 1970; Tompkins \& Gonzaga, 1989; Read et al., 2004).

Alluvial diamond deposits occur in the Borrachudo River and some of its tributaries (Figure 1, featured on the right side). In the studied area, the deposits are related to three periods, all of them probably of Holocene Era (Reis, 2011). The oldest one occurs as alluvial terraces, elevated up to $20 \mathrm{~m}$ relative to the current channel of the river and consists of unconsolidated gravels with variable thickness up to $2 \mathrm{~m}$. Paleochannels of younger eras occur on both banks of the river (about $2 \mathrm{~m}$ above its actual trough), whose remnants are up to $8 \mathrm{~m}$ thick (2-3 $\mathrm{m}$ of basal gravel and 30-35 m wide); these deposits are currently undergoing mining activity and its diamonds are the focus of this study (Figure 2A-B). The younger deposits are alluvial sediments of the riverbed.

Figure 2

(A) Mined diamondiferous gravels (paleochannel) at the Borrachudo River, where the diamonds were recovered (contact in red). (B) General view of part of the studied diamond parcel.

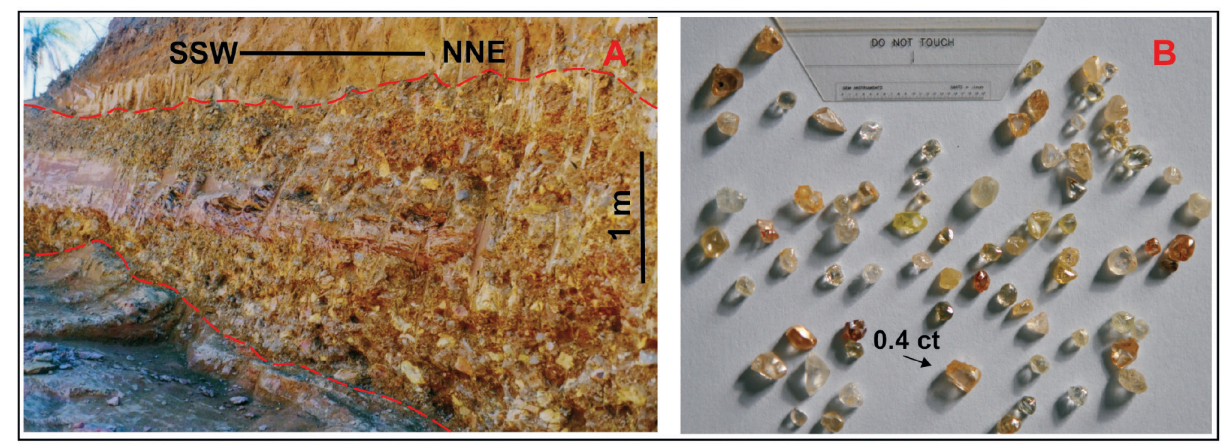

\section{Physical aspects of the diamonds from the Borrachudo River - Results}

The physical characteristics of the diamonds are very important to understand their primary sources, to define different genetic "families", as well as to understand their primary paths, the surface distances from the source rock until its deposition site in the alluvium. Several authors have studied the morphology and dissolution figures of diamonds, using both descriptive and statistical methods in primary and secondary deposits (e.g.

\section{Weight (ct)}

The weight ranges were selected according to the general pattern observed in diamonds from the Western São Francisco Diamondiferous Province, according to the original proposal of Chaves $\&$ Chambel (2003). In the studied parcel,

Figure 3 (A) Weight patterns of weight recorded in diamonds from the Borrachudo River in relation to the number of studied crystals.

(B) The same situation in relation to total weight of stones (both in \%).

\section{Morphology}

The most common growth forms of the studied diamonds are the cube $\{100\}$, octahedron $\{111\}$, and rhombic dodecahedron $\{110\}$ (Figure 4). The
Svisero, 1971; Harris et al., 1975; Chaves, 1997; Martins, 2006), as well as by purely experimental methods (e.g. Orlov, 1977; Kosai \& Arima, 2005; Khokhryakov \& Pal'yanov, 2007).

The knowledge of the diamond transformation processes from their original form may indicate the fundamental conditions of formation of their host bodies, and the dissolution of the crystals in the ascent magma presents aspects other than those occurring in the river system. In the present study, the physical parameters are shown in four different interconnected parameters: characterization of crystal weight and morphological patterns, both indicating the transformation degree by dissolution; their dissolution figures, which show the relative stage of this process; and the abrasion, which is the final shape produced by mechanical wear during the fluvial transport. a numerical predominance of samples weighing up to $0.30 \mathrm{ct}(\sim 51 \%)$ occurs, followed by another range between 0.31 and 1.00 ct $(\sim 37 \%)$ (Figure $3 \mathrm{~A})$. The presence of some diamonds weighing over $20 \mathrm{ct}$ was also detected. Thus, taking into consideration all weight categories, including isolated larger stones, this situation changes considerably, showing a significant percentage ( $47 \%)$ concentrated in the range heavier than 3 ct (Figure 3B).

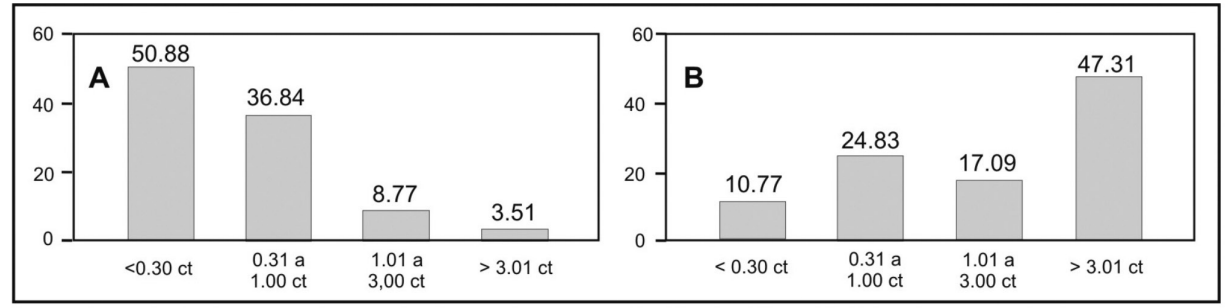

crystals may often not have definite shapes (as chips and flats) due to disproportions in the growth given by different speeds along specific crystal- lographic axes. In general, the dissolution process naturally causes a gradual bulging of the crystal surfaces and thus new shapes are produced. 


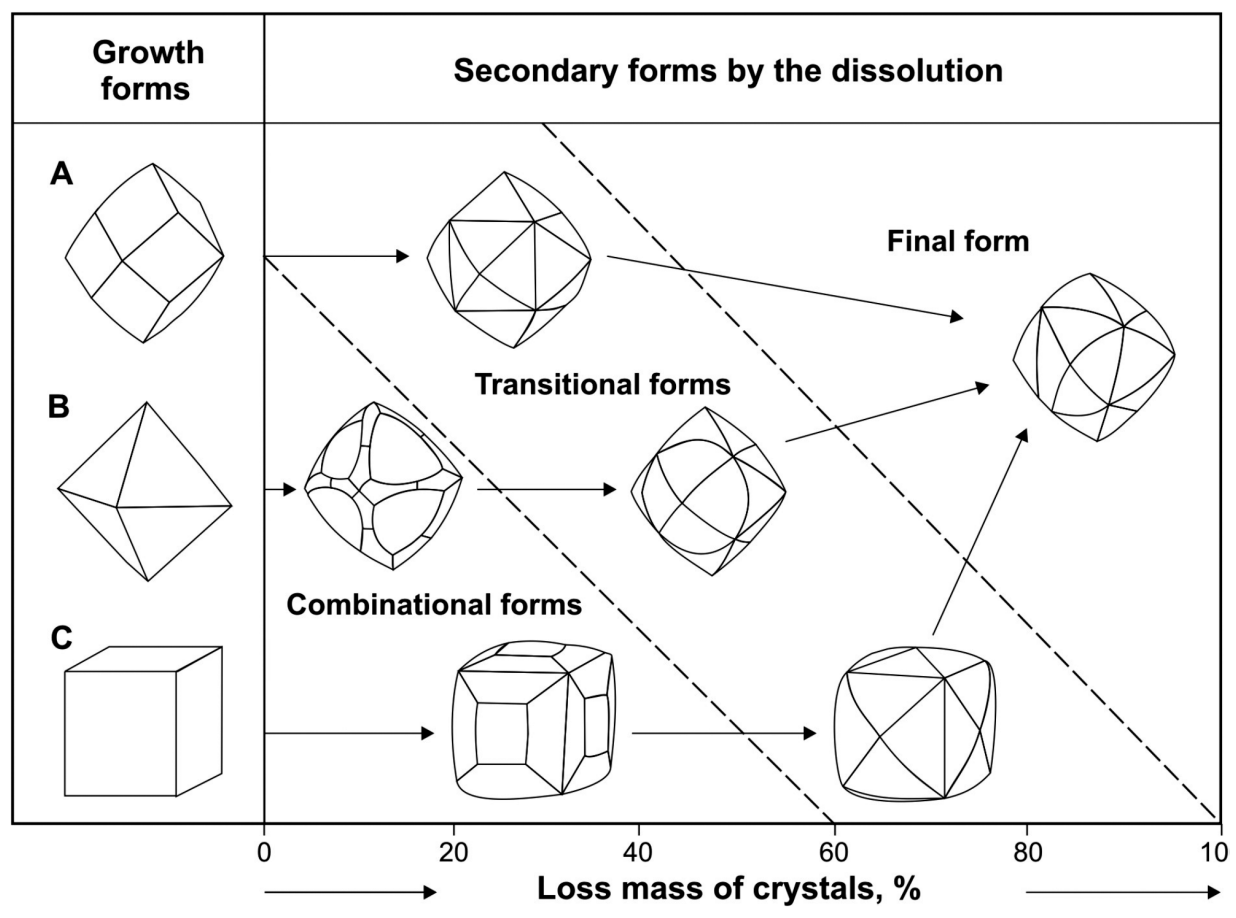

Recent experimental studies by Khokhryakov \& Pal'yanov (2007) showed a change in morphology from octahedrons, rhombic dodecahedrons and cubes to final tetrahexahedroids forms by progressive dissolution, though involving different rates of mass loss (Figure 4). In this way, rhombic dodecahedrons only lose $10 \%$ of mass, while octahedron loses $20-25 \%$, and in cubes, the mass

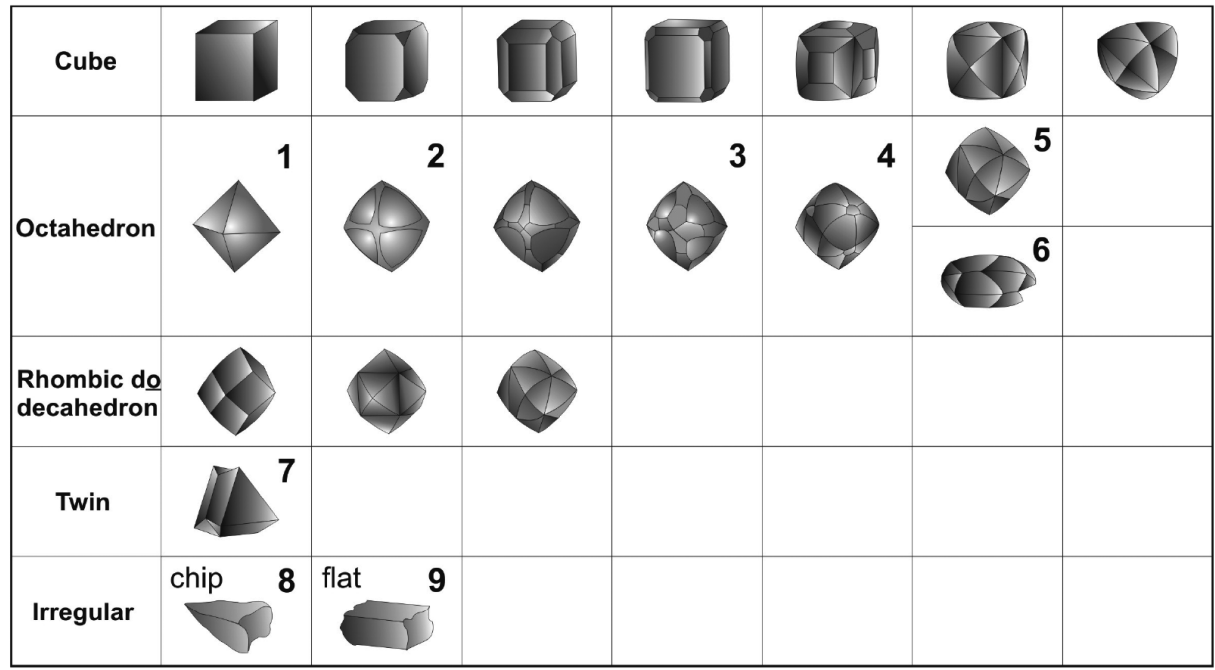

Diamonds from the Borrachudo River have interesting differences regarding their shapes in relationship with the weight ranges. Weights between 0.01 and $0.30 \mathrm{ct}$ present very different forms, while the 0.31 to $1 \mathrm{ct}$ range only shows octahedral shapes and its descendants. In samples over $1 \mathrm{ct}$, the chip and flat types predominate. The morphology of the crystals indicates that the dissolution process has been highly developed, as identified by final tetrahedroid forms, as
Figure 4

Theoretical scheme of the diamond morphological evolution from its fundamental forms during the dissolution processes (A, rhombic dodecahedron; $\mathrm{B}$, octahedron; C, cube) (according to Khokhryakov \& Pal'yanov, 2007).

loss is greater than $50 \%$. A complete presented sequence of the form evolution (Figure 5) was based on Svisero (1971), Khokhryakov \& Pal'yanov (2007), and Borges (2013).

Figure 5

The crystallographic forms of diamond separated by the primary stage of growth, and its different secondary combined forms (adapted on Svisero, 1971; Khokhryakov \& Pal'yanov, 2007; and Borges, 2013 - numbers 1 to 9 refer to the shapes observed in the studied diamonds).

well as the chips and flats (Tables 1 and 2, Figure 6). By the detailed study of the parcel, it could be demonstrated that all of it was formed by the progressive dissolution of octahedral shapes, or by twin of octahedron, chips and flats (Figure 5).

\begin{tabular}{c|ccccccccc}
$\begin{array}{c}\text { Form / Weight } \\
\text { (ct) }\end{array}$ & $\mathbf{1}$ & $\mathbf{2}$ & $\mathbf{3}$ & $\mathbf{4}$ & $\mathbf{5}$ & $\mathbf{6}$ & $\mathbf{7}$ & $\mathbf{8}$ & $\mathbf{9}$ \\
\hline $\mathbf{0 . 0 1 - 0 . 3 0}$ & 0.00 & 2.63 & 7.02 & 4.39 & 10.53 & 7.02 & 0.88 & 15.79 & 2.63 \\
$\mathbf{0 . 3 1 - 1 . 0 0}$ & 0.00 & 5.26 & 0.88 & 4.39 & 7.89 & 6.14 & 2.63 & 5.26 & 4.39 \\
$\mathbf{1 . 0 1 - 3 . 0 0}$ & 0.88 & 0.88 & 0.00 & 0.00 & 0.88 & 0.88 & 0.00 & 1.75 & 3.51 \\
$>\mathbf{3 . 0 1}$ & 0.00 & 0.00 & 0.00 & 0.00 & 0.88 & 0.00 & 0.00 & 1.75 & 0.88
\end{tabular}

Table 1

Relationship between weight ranges and crystallographic forms, considering the total number of samples (in \%; shape numbers as in figure 5). 
Table 2

Relationship between weight ranges and crystallographic forms, considering the total weight of the sample (in \%; shape numbers as in figure 5).

Figure 6

Relationship between the weight ranges according to the number of samples in the respective crystallographic forms (shape numbers as in figure 5).

\section{Dissolution figures}

According to many authors (e.g. Kozai \& Arima, 2005; Khokhryakov \& Pal'yanov, 2007) the dissolution figures develop in a sequential line, where three stages in the process are recognized: (1) initial stage, where negative or positive trigons appear, as well as hillocks in blocks

Table 3

Dissolution figures present in the initial (trigons, hillocks in blocks or pseudopyramids), intermediate (secondary cleavage,

residual hillocks, lamination lines and undulation), and final (holes and patina like) stages (form numbers as in figure 5). Individual stones were examined under a binocular microscope with 40x magnifier.

Evolution of the crystallographic form of the diamonds from the Borrachudo River can be seen in figure 7 . The original faces are gradually replaced

\begin{tabular}{c|ccccccccc}
$\begin{array}{c}\text { Form / } \\
\text { Weight } \\
\text { (ct) }\end{array}$ & $\mathbf{1}$ & $\mathbf{2}$ & $\mathbf{3}$ & $\mathbf{4}$ & $\mathbf{5}$ & $\mathbf{6}$ & $\mathbf{7}$ & $\mathbf{8}$ & $\mathbf{9}$ \\
\hline $\mathbf{0 . 0 1 - 0 . 3 0}$ & 0.00 & 0.41 & 1.48 & 0.72 & 2.50 & 1.40 & 0.29 & 3.31 & 0.67 \\
$\mathbf{0 . 3 1 - 1 . 0 0}$ & 0.00 & 3.71 & 0.46 & 2.70 & 5.87 & 4.58 & 1.44 & 3.21 & 2.86 \\
$\mathbf{1 . 0 1 - 3 . 0 0}$ & 1.60 & 1.59 & 0.00 & 0.00 & 1.31 & 1.73 & 0.00 & 2.86 & 8.01 \\
$>\mathbf{3 . 0 1}$ & 0.00 & 0.00 & 0.00 & 5.44 & 0.00 & 0.00 & 0.00 & 37.26 & 4.61
\end{tabular}

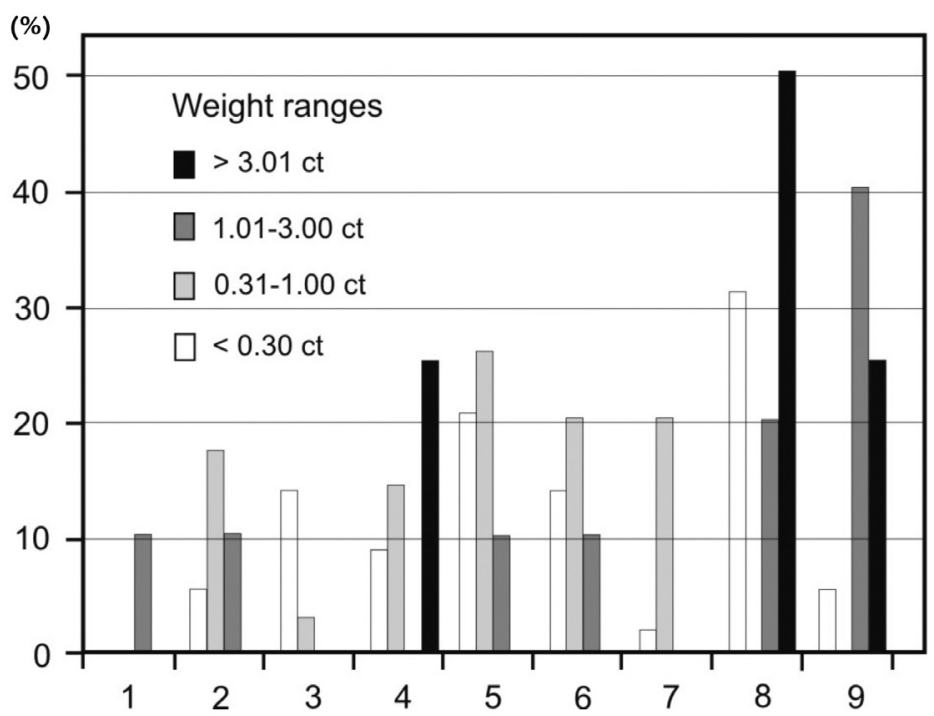

or pseudopyramids; (2) intermediate stage, showing secondary cleavage, residual hillocks, lamination and undulation lines; and (3) final stage, with the formation of holes and patina like.

Among the dissolution figures, hillocks in blocks and pseudopyramids predominate, followed by positive trigons and secondary cleavage, mainly in chip type diamonds. Another observation is that in the octahedron the morphological evolution is accompanied by dissolution figures in their respective dissolution stages (Table 3).

\begin{tabular}{l|ccccccccc}
$\begin{array}{l}\text { Shapes / Dissolu- } \\
\text { tion figures }\end{array}$ & 1 & 2 & 3 & 4 & 5 & 6 & 7 & 8 & 9 \\
\hline Trigons & 0.00 & 50.00 & 44.44 & 18.18 & 4.55 & 12.50 & 25.00 & 25.00 & 23.08 \\
\hline $\begin{array}{l}\text { Hillocks in blocks/ } \\
\text { pseudopyramids }\end{array}$ & 0.00 & 20.00 & 44.44 & 45.45 & 36.36 & 12.50 & 75.00 & 25.00 & 30.77 \\
\hline Secondary cleavages & 0.00 & 10.00 & 22.22 & 27.27 & 13.64 & 12.50 & 25.00 & 39.29 & 69.23 \\
\hline Residual hillocks & 0.00 & 0.00 & 0.00 & 0.00 & 4.55 & 0.00 & 0.00 & 7.14 & 7.69 \\
\hline Lamination lines & 0.00 & 20.00 & 0.00 & 0.00 & 4.55 & 0.00 & 0.00 & 10.71 & 7.69 \\
\hline Undulations & 100.00 & 0.00 & 0.00 & 9.09 & 0.00 & 18.75 & 0.00 & 3.57 & 0.00 \\
\hline Holes & 0.00 & 0.00 & 0.00 & 9.09 & 18.18 & 12.50 & 0.00 & 25.00 & 15.38 \\
\hline Patina like & 0.00 & 0.00 & 11.11 & 0.00 & 9.09 & 6.25 & 0.00 & 3.57 & 0.00 \\
\hline
\end{tabular}

following the sequence from the octahedron to the rhombic dodecahedron: $\{111\} \rightarrow\{111\}+\{110\} \rightarrow\{110\}+\{111\}$ $\rightarrow\{110\}$. In octahedral and descendant shapes, the evolution of the dissolution figures is correlated to the different dissolution stages; in other words, the greater the shape evolution degree, the 
more final-stage dissolution figures appear. In chip and flat diamond types,

dissolution figures show the three distribution stages approximately in the

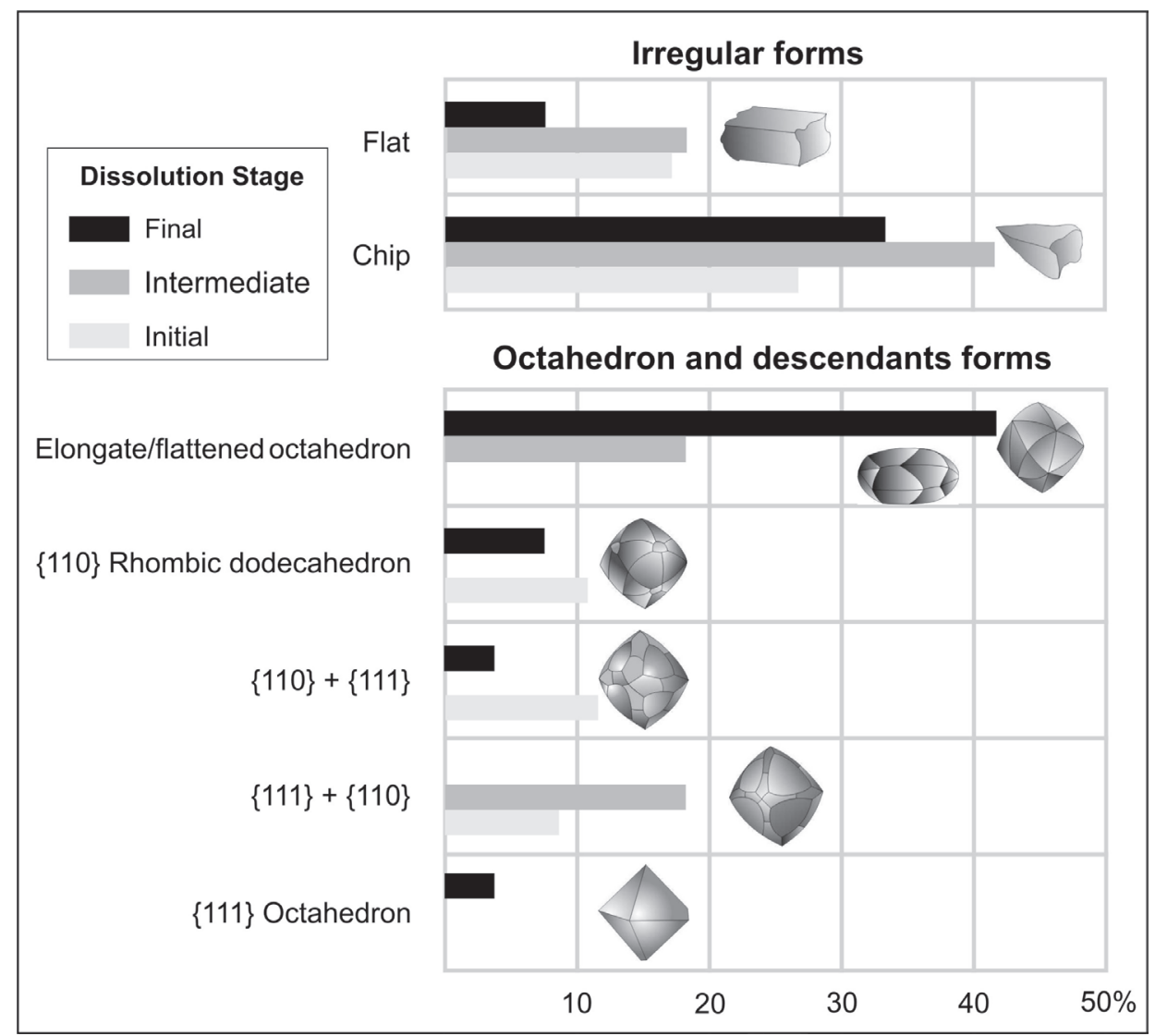

\section{Abrasion}

Abrasion is the mechanical wear process given by fluvial transport. In the studied population, diamonds of the Bor-

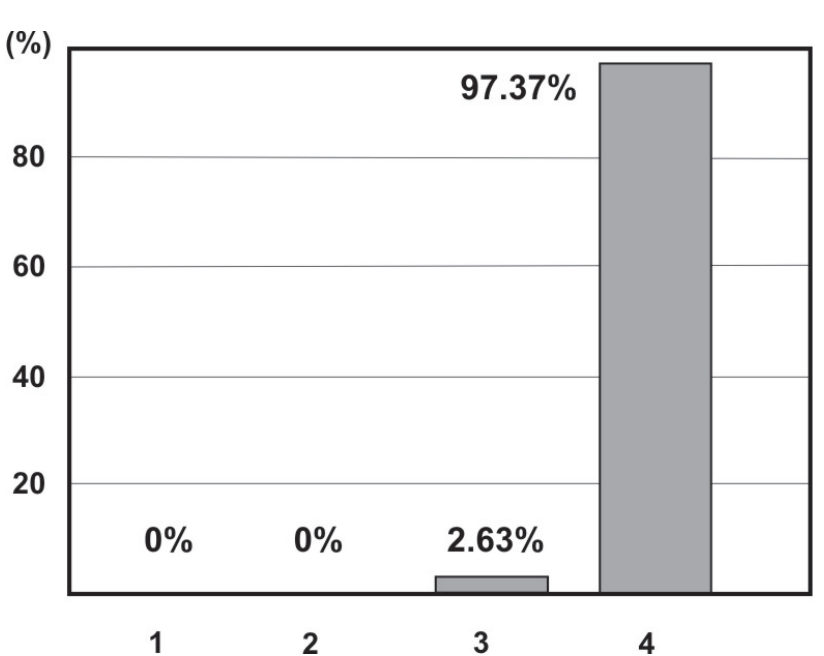

\section{Concluding remarks}

The origin of diamonds from the region related to the Abaeté, Borrachudo, and Indaiá rivers has always been a conundrum. Unlike the adjacent province to the southwest (Alto Paranaiba Province), where dozens of kimberlite intrusions in Coromandel and surrounding municipali- same proportions.

Figure 7

Relation between crystallographic forms and dissolution figures in diamonds from the Borrachudo River and sample frequency.

This means negligible transport, and therefore the source area was relatively near (Figure 8).
Figure 8

Frequency diagram of abrasion in diamonds from the Borrachudo River: 1. No original facet; 2 . Small visible original facets; 3 . Worn vertex and edges; 4 . No signs of mechanical wear and/or bearing.

rivers, extensive regions of volcanic and volcanoclastic rocks of the Mata da Corda Group (Upper Cretaceous) occur, hiding possible kimberlite intrusions. However, the presence of tributaries with diamond occurrences (as in the Grande, Águas Claras, and Carrão streams - Figure 1 
detail) is also known. Such streams do not emanate from the headwaters of the Borrachudo River, indicating the possible existence of more than one area of primary mineralizing rock sources, not discarding the possibility of Cretaceous deposit reworking. Similar to what occurs in other alluvial systems in the region, such as in the Abaeté and Sono rivers (Chambel \& Chaves, 2003), it is probable that a mixture of diamonds from different

\section{Acknowledgements}

The first author thanks the IGC/ UFMG, where he finalizes his Master's sources occur.

The weight pattern showed that most of the parcel is below $0.30 \mathrm{ct}$, although larger samples are also found, in the shape of chips or flats. Thus, the study characterized two distinct families identified by: (1) well-formed crystals, always from octahedral shapes and its descendants, and (2) larger size chips and flat crystals. The morphology associated with the dissolution figures indicates that they have suffered intense alteration into the kimberlite (Tappert \& Tappert, 2011), and that some of these features still suffered final corrosive attacks, resulting in holes and "patina" in the surface. The diamonds have not been subjected to abrasion, and the existence of chips with sharp edges indicate that the transport was slightly significant, reinforcing the idea of a possible proximal source for majority of the studied parcel.
Thesis. M. Chaves thanks CNPq for granting the research productivity schol- arship and the facilities granted by Petrus Mining Co.

\section{References}

BARBOSA, O. Diamante no Brasil - histórico, prospecção e lavra. Rio de Janeiro: CPRM Editora, 1991. 136p.

BARBOSA, O. et alii. Geologia da região do Triângulo Mineiro. Boletim DNPM/DFPM, v.136, p.1-140, 1970.

BORGES, L.A.D. Mineralogia e aspectos gemológicos do diamante da região do rio Borrachudo (Tiros. MG). Belo Horizonte: IGC - Universidade Federal de Minas Gerais, 2013.185p. (Master in Sciences Disssertation).

CHAVES, M.L.S.C. Geologia e mineralogia do diamante da serra do Espinhaço em Minas Gerais. São Paulo: IG - Universidade de São Paulo, 1997, 289p. (Doctorade Thesis).

CHAVES, M.L.S.C., CHAMBEL, L. Diamante: a pedra, a gema, a lenda. São Paulo: Oficina de Textos, 2003. 231p.

FUCK, R.A., PEREIRA, R.S. Archean nucleii and the distribution of kimberlite and related rocks in the São Francisco craton. Brazil. Revista Brasileira de Geociências, v.35, p.93-104, 2005.

HARRIS, J.W. et alii. A classification scheme for diamond and a comparative study of South African diamond characteristics. Physics and Chemistry of the Earth, v.9, p.765-783, 1995.

HEINECK, C.A. et alii. Mapa geológico do Estado de Minas Gerais, Escala 1:1.000.000. Belo Horizonte: COMIG/CPRM Agreement, 2003. 1 folha.

KHOKHRYAKOV, A.F., PAL'YANOV, Y.N. The evolution of diamond morphology in the process of dissolution: experimental data. American Mineralogist, v.92, p.909917, 2007.

KOZAI, Y., ARIMA, M. Experimental study on diamond dissolution in kimberlitic and lamproitic melts at $1300-1420^{\circ} \mathrm{C}$ and $1 \mathrm{GPa}$ with controlled oxygen partial pressure. American Mineralogist, v.90, p.1759-1766, 2005.

MARTINS, M.S. Geologia dos diamantes e carbonados da bacia do Rio Macaúbas (MG). Belo Horizonte: IGC-Universidade Federal de Minas Gerais, 2006. 231p. (Doctorate Thesis).

ORLOV, L.Y. The mineralogy of diamond. New York: Wiley \& Sons, 1977.235p.

READ, G. et alii. Stratigraphic relations, kimberlite emplacement and lithospheric thermal evolution, Quiricó basin, Minas Gerais State, Brazil. Lithos, vol.77, p.803-818, 2004.

REIS, H.L.S. Folha SE.23-Y-B-V - Serra Selada, Mapa Geológico, Escala 1:100.000. Belo Horizonte: UFMG/CODEMIG/CPRM Agreement, 2011. 1 sheet.

SVISERO, D.P. Mineralogia do diamante da região do Alto Araguaia. Mato Grosso. São Paulo: IG - Universidade de São Paulo, 1971. 127p. (Doctorate Thesis).

TAPPERT, R., TAPPERT, M.C. Diamonds in nature: a guide to rough diamonds. Berlin: Springer, 2011. 142p.

TOMPKINS, L., GONZAGA, G.M. Diamonds in Brazil and a proposed model for the origin and distribution of diamond in the Coromandel region, Minas Gerais, Brazil. Economic Geology, v.84, p.591-602, 1989. 